\title{
The Relationship between the Innocence and the Authority
}

\author{
Delara NematiPir Ali (Ph.D) \\ Department of Quran and Hadith Sciences, Karaj branch, Islamic Azad University, Karaj, Iran \\ Email: dlrnemati@gmail.com, Mobile: 009809122181021
}

\section{Mojgan Khanbaba (Ph.D)}

Department of Quran and Hadith sciences, Islamic Azad University 'Tehran - Iran

Email: Moj.khanbaba@gmail.com, Mobile: 00989126605916

DOI: $\quad 10.6007 /$ IJARBSS/v3-i8/164 URL: http://dx.doi.org/10.6007/IJARBSS/v3-i8/164

\begin{abstract}
The Innocence as a religious validity criterion is one of the most fundamental twelve-Imam Shiite beliefs. This word, Innocence (esmæt), in special meaning means absolute purity of soul from all impurities, vices and wickedness and allocates to the principles of Shiism. On this basis, the innocence is an internal, heavenly and genetic power which is allocated to the prophet's people of the house by God's will. But because the authority is one of the necessities of stability and durability of innocence, we can prove the innocence of twelve Imams by clarifying its relationship with authority. In this approach, having a sound and complete knowledge of God and obeying him devotionally is the introduction of spiritual light and the utmost of the intellect and accessing to the real Unity and a monotheist can access to a live heart which results in permanent The remember an coed Allah and love and it can remove the material veils from the human being and make them capable of realities intuition. This knowledge and intuition prevent him from doing filths and perversions and also attributes him to internal purity and innocence.
\end{abstract}

Keywords: innocence, knowledge, obedience, intellect, heart, eternal life.

\section{Introduction}

The category of " innocence " among the twelve-Imam Shiite beliefs, is the most important religious validity criterion and the most original feature related to Imamate divine post. Albeit, the Holy Quran doesn't use the word of " innocence " and " innocent " in their terminological meaning but illuminates them in different expressions. For example: "Allah only desires to keep away the uncleanness from you , O people of the House! And to purify you a thorough purifying (Q.33:33) this verse has propounded the Prophet's Family purity from all uncleanness and filthes. This purity is a special purity which is ascertained by God's formative will. (Tabatabaei, 1996) The other interpretation which suggests the concept of "innocence" is "Mokhællæs " in objective form that based on Quran verses attributes to those ones who are away from the evil's deceits.(Q.38: 82 - 83) 
Here is a question: Is Innocence the grace of God that is given to the Prophets and Imams compulsively or it is their divine personality which is the source of innocence state? In the other word: What is the source of Imams' innocence? Because the innocence can be considered in two aspects:

1. The divine innocence means: God achieves his formative will and creates a kind of motivation in the human beings by which all their actions appear correctly and obediently.(Tabatabaei,1996)

2. Getting innocent is as a result of authority inman's thoughts and actions with due attention to its lexical meaning : whatever the human beings seek refuge to.(Farahidi,2013)

Believing merely in the first meaning leads to be under compulsion so the Imams' authority and will has no sense. The result of such a belief is declining from the noble paradigm state because the comprehensive patterns of people should have the authority, will and freedom like them so that his reaction to man's wills can be capable of sampling.(Yousefian,2009)So on the issue of deep rooted innocence it can be supposed that in addition to God's grace , authority and will are effective. This issue is capable of following up and studying by Quranic and traditional instructions.

\section{The innocence Semantics:}

"æsæmæ " means prohibition and preventing. In other word, God repels and prohibits human beings from all evils and badness's (Farahidi,2013) and protect them.(Ibn Manzour,1997) Its main meaning is protecting with defense. When it is told "æsemætho" means I protect with defending him. In this case the "protector "and "Protected "are two sides of innocence. It means who protects and whom or what is protected." E'tesām "means choosing innocence, in other word someone wants to be safe with protecting himself from what is harmful. "Esmæt "is an infinitive which means achievement of protection and defending it. So refuting, adherence, prevention, saving and protection are important for the meaning of :"æsæmæ".(Mustafavi,1971)So there are two terms : protection and dependence " in "Esmæt" meaning and its attribution to God means: God saves man from every evil and badness and repels him from them and its attribution to man means he prohibits himself from evil and badness by refuting to God. According to "E'tesām" meaning , that is choosing prohibition and dependence,(Mustafavi,1971) it can be said that the authority is one of necessities of the innocence because the innocence in its terminological meaning is a spiritual deep rooted feature which prevents man to do wrongs,(Tabatabaei,1996) which is the result of God's obedience in one's optional acts and behaviors. So choosing the innocence means constant refuting to God and resorting to permanent God's devotion. So we can find a meaningful relationship between God's obedience which is something related to man's authority and enjoying innocence and also its stability and transcendence in one's soul. It means two sided relationship between God and His servant in the innocence issue. It means: God grants and man uses his authority in absolute obedience of God. So we can determine the source of stability, manifestation and transcendent of innocence as: 


\section{Knowledge and obedience}

Knowledge is one of the most important element in making a right and complete relationship between God and man that has a wide domain and in addition to God's knowledge and himself, it includes knowledge of life and death and the truth of sin and obedience and their effects. Such a complete knowledge grants man an insight that he can purify all his thought and actions and leads them to God's satisfaction so he can get to God's worshiper state.

The exact knowledge of God, in Zahra's word -in place of an innocent - is presented as: I attest there is no one but Allah. He is the One and has no partner. This attestation is a word that God grants sincerity as its result (Tabarsi, 2007). It means she knows the achievement of sincerity in actions and thoughts as a result of knowledge of God's unity and it means he is responsible for God. In her opinion, God is beyond of material and His great fullness cannot be understood by human beings (the eyes cannot see Him and the tongues and thoughts cannot describe him)(Tabarsi,2007).

God is an innovator and independent who has a magnificent aim in creating the world: ( He creates things without any need and profit of them but shows his stability and durability of his theology and boundless power and informs them about obeying his commands and grants them his devotedness.(Tabarsi,2007)He is the One who ordains reward and chastisement for man's gain: he ordains reward for men's obedience and chastisement for disobedience in order to save them from divine retribution and leads them to paradise.(Tabarsi,2007)That Excellency, Fatimah Zahra, in this short word, explains the life and death and sin and obedience concept meanwhile shows a complete theology and anthropology as well. In her opinion, God is the sole and unmatched creator who cannot be understood by human perception so he can receives to God's knowledge by heart and belief as Ali Ibn Abitalib says : The eyes cannot see Him evidently but the hearts can comprehend Him the real faith.(Dashti :178)and in this view, man is purposeful and responsible whose extreme aim of creation is to receive God's knowledge, get the servitude favor and achieve sincerity in actions and thoughts and the life is a good opportunity for man's transcendence that can be achieved under God's obedience.

Since obedience depends on knowledge, That Excellency, while explaining the philosophy of divine legislations and relying on Quranic verses, knows the introduction and way of journey to God with support of God's knowledge and obedience: God purifies you from the paganism for the sake of your faith and ordains prayer(Sælæt) for purifying you from pride and arrogance and also ordains charity tax(Zakat) for purifying your souls and increasing your sustenance and the fast for stability and durability of your sincerity. So you who believe in God! Be careful of your duty to Allah with the care which is due to Him and do not die unless you are Muslims and obey Allah in whatever he commands and prevents you because only those who understand are careful of their duty to Allah.(Tabarsi,2007) In this view, the true obedience is action under knowledge beams and after it the development of human's souls that it deserves him for God's rewards and the truth of sin is descending and self-extinction of man which deserves him for God's pain. In the Quranic view the last aim of man's creation is journey from creature to the creator: 'What! Did you 
then think that we had created you in vain and that you shall not be returned to us? (Q.23:115).

So it is clear that God's reward is: returning and becoming closer to Him as Allah says in Quran: "O souls that are at rest! Return to your Lord, well-pleased with him, well-pleasing Him (Q.89:27\&28). In this meaning, God's torture is the fire of the avoidance of God. On the basis of Zahras's philosophy, man is permanently interacting to God who brings to life and his sincere obedience causes proximity of God. And also committing the crimes leads God's torture and punishment. It is obvious that such acumen saves man in permanent taking care of himself and resorting to God.

\section{Perfection and Brightness of intellect:}

Imam Sadegh (Pbuh) introduces intellect in this way: the intellect is something by which God is worshiped and the paradise is gained through it.(Kuleini, no date)This word makes clear that the intellect is an intermediate of man and God. It means the man's tool for reception of reality is the intellect since it is addressed to God's speech as Imam Bagher (pbuh) said: When Allah created intellect makes him to speak and said to it: come to me so it came to Him then Allah said: Come back so it Came back then He said I swear to my Honor and Glory that I have never created such a lovely created being and I grant you completely to those ones whom I love them. Know that my commands, prohibition, reward and chastisement are addressed to you.(Kuleini, no date) On the basis of this tradition, the intellect is addressed to God's commands and prohibitions and one who has a full of intellect can follow all God's commands and prohibitions and one receives the full of intellect whom is beloved of God. On this basis, there is a strong relationship between God's favoriteness and his absolute obedience. The obedience of man makes him lovely near his God and it enjoys him of the full intellect favor and the full of intellect causes a right knowledge to God because God's knowledge to partial perceptions of man cannot be obtained but by the intellect brightness and spiritual perception. It means to get specifically that is a kind of achievement not a mere knowledge. So the achievement of being monotheist in the human being is as a result of spiritual perception and brightness of the intellect(Baha Al-Dini,2001).The perfection and brightness of the intellect makes human monotheist in real meaning and believing in the oneness of God is the means of spiritual life as Imam Ali said :Believing in the oneness of God is the real life of man's soul.(Amadi,2003)so the perfection of the intellect causes man to be a real monotheist and have a real life.

\section{The heart life}

Relying on this noble verse: "Allah does not call you to account for what is vain in your oaths, but He will call you to account for $w$ hat your hearts have earned "(Q.1:225) man's life is he himself and his soul (Tabatabaei, 1996). Which has different states? Imam Sadegh expresses these states : the hearts states are four kinds: the heart peak that is the real blooming of soul and is as the result of The remembrance of Allah, the heart relief that is the being expansion and is as the result of God's satisfaction, the heart down falling that is the human's decline and is as the result of attention to non-God, and the last one : the heart stopping which is losing dynamic and energetic human's life that is the result of forsaking God.(Majlessi,1982)it means 
that man's soul ascension depends on the remembrance of God as Imam Ali said : God prescribed his memory for heart's shining.(Dashti,2001) so the heart decline, depression and stopping is as the result of forsaking of God and it leads to sins and committing the sins leads to heart death as Imam Sajad said : My Lord! The greatness of my sin caused the death of my heart (Majlessi, 1982). The Holy Quran explains the result of the forsaking of God in this way: "and be not like those who forsook God, so He got them to forsake their own souls: these it is that are the transgressors."(Q.59:19)Based on this verse, forsaking of God caused men's selfforsaking and enters man to the circle of debauchery because such a man who forsakes his God and his returning to Him and avoids from His memory and pays attention to non-God and forgets his real existence which is an absolute poverty and considers himself as those who can plan their issues independently,(Tabatabaei ,1996)and self-conceit causes heart death and to get involved in sins since it can be said that this verse orders God's memory and obedience.(Tabatabaei,1996)Because The remembrance of God causes the remembrance of His divine names and attributes that humans' internal poverty relates directly to it, In this case, man remembers his internal poverty and relies on God,(Tabatabaei,1996)and this is the very useful knowledge that leads to The remembrance of God and the human real life.

\section{The permanent remembrance of Allah and unveiling}

Man has two births : one is his world mode of being and the other is his Divine real of being(Khumeini,2002).The first one is the world of sensation and the second is the heart world so the heart has a world too as the other one and there are laws and effects for heart like the sensation world(Tabatabaei,2006).In different verses of Holy Quran, the man's guidance and misguidance are attributed to inward organs and parts, in those verses that pagans are described as deaf , dumb and blind people : " and the parable of those who disbelieve is as the parable of one who calls out to that which hears no more than a call and a cry; deaf, dumb and blind, so they do not understand"( Q.1:171) in the other verse, those who cannot see warnings are described as blind hearted people: " have they not travelled in the land so that they should have hearts with which to understand, or ears with which to hear ? for surely it is not the eyes that are blind, but blind are the hearts which are in the breasts " $(Q .22 / 46)$ The holy Quran describes the reason of standstill of heart's members as "Nay! Rather, what they used to do has become like rust upon their hearts "(Q.83:14)We can use three points in this respect From the Quranic verses:

1. Human's soul based on its prime nature has purity and clearness that understands the reality and recognizes goodness and badness as God says in the Holy Quran : "and the soul and Him Who made it perfect, then He inspired it to understand what is right and wrong for it " (Q.91: 7 \& 8)

2. The ugly things act as the human's soul and the human's soul as they come.

3. These figures prevent human's soul to realize the reality and truth.(Tabatabaei,1996)Because of such a debarred heart of realizing the truth, such a man is debarred from Lord's nearness at the Day of Resurrection : "Nay! most surely they shall on that day be debarred from their Lord ".(Q.83:15) 
On the other hand, God conveys the believers and righteous people good news:" and conveys good news to those who believe and do good deeds "(Q.1:25) This good news contains Paradise and its bounty that is described in many verses but is not confined to it. The upper levels of faith lead to upper Paradise bounties. In the Quran view the perfect faith is accompanied with perfect obedience toward the fundamental and branches of religion which the Holy Prophet presented: "But no! By your Lord! they do not believe in reality until make you a judge of that which has become a matter of disagreement among them, and then do not find any straitens in their hearts as to what you have decided and submit with entire submission (Q.4:65).Such a complete and perfect following which is the result of exalted faith leads to Lord's affection: "Say: if you love Allah, then follow me, Allah will love you too. " (Q.2:31) And the Lord's affection causes the human's intellect brightness in addition to Lord's generosity and mercifulness as Allah addressed to intellect in Imam Bagher's word :" O you Intellect! I grant you completely only to those ones whom I liked them" (Kuleini,no date). Based on it, those who follow the Holy Prophet completely in fundamental and branches of religion are the owner of the bright full intellect who get to the real life, because Allah knows his obedience in the Prophet's obedience :" Whoever obeys the Prophet, he indeed obeys Allah " (Q.4:80)also knows the condition of Divine light in believing in the Holy Prophet and following him : "O you who believe ! be careful of your duty to Allah and believe in His Apostle :He will give you two portions of His mercy, and make for you a light with which you will walk, and forgive you and Allah is forgiving , Merciful " (Q.57:28)

So getting the high degree of faith means virtue of God and absolute Prophet's following and its result is getting two benefits of divine grace: One for the basis of monotheism and its degrees and the other for attending to Divine light .(Gharashi,1998) and this light is alive soul by which man is revived.(Tabatabaei,2006)and he gets busy with the God's permanent remembrance and God is not a man of withdrawal because God has not given a man two hearts and souls :" Allah has not made for any man two hearts within him " (Q.33:4) so the absolute heart attention to God and the complete occupation to The remembrance of Allah can be accessed and continued by man's avoidance of material and world amusements(Tabatabaei,2006).The continuation of such a mood causes God's affection and repels the material veils in front of heart eyes. As the Prophet (s.w) said :Allah says: whenever my remembrance conquers my servant, I put his satisfactory and wills in my remembrance and when I do it he becomes my lover and so do I. When we love each other, I remove the veils between him and me and then I prevails my love in his soul so that he is not like the other people who forsake and oversight (Reishahri, 2006).

Removing veils from man's soul is described in one of Imam Zein Al-Abidin's traditions: Know that the God' servant has four eyes: two eyes to see the world and religion issues and two eyes to see hereafter issues so whenever Allah wills his servant's benefit, opens the two eyes in his heart by which he can see the supernatural world.(Majlessi,1982)

The Shiite Imams (as) who are standing on the devotion, surrender and insight lofty peak get to the absolute divine vision and are attributed to the major innocence as Imam Reza Said : We have eyes which are not people's eyes and there is a light where the Satan does not contribute it.(Majlessi,1982 )Since the household of the Prophet are Divine proof on the earth 
and Allah's chosen men as Zahra introduced her family and herself : We, the prophet's household, are the means of Allah's relationship to the people. We are Allah's selected people and the place of divine purities. We are the divine proof and prophets' heirs.(Ibn Abi Al- Hadid ,1999).

\section{Conclusion}

Although based on the Tathir Verse (Q.33:33) and many different verses and traditions, Allah granted the Innocents(ma'soumin) the innocence(esmæt) grace based on His genetically and final will, but with due attention to the divinity and internality of innocence force which saves his owner from all defections and shortcomings such as sins, nonparties and wickedness's and the Divine protection means choosing the innocence which is Allah's obedience in thoughts, actions and motivations, we can prove the Innocents' innocence with the relationship to authority and freedom in man's actions. We should also consider that the protection, stability, continuation and elevation of innocence grant is related to complete knowledge and the full of intellect and to be admitted to the absolute recognition of Allah's unity under using the authority in the right way in which the heart life and permanent Allah's memory followed it and removes the material veils in front of man's insights and reaches him to intuitional knowledge that such a knowledge is not accompanied with ignorance and neglect so prevents one to become afflicted with nonparties and filths.

\section{References}

\section{**The Holy Quran}

1. Dashti, Muhammad, (2001) Nahj Al-Balagheh of Ali Ibn Abi Talib (Pbuh) , publisher:Hozour publicational institution , (Lectures:178 \&222)

2. Amodi , Abd Al-Vahid ,(2004) Ghorar Al-Hikam \& Dorar Al-Kalim , Translated by: Hashim Rasouli Mahallati, publisher: Islam Culture Publicational office,v.2, p.530.

3. Ibn Abi Al-Hadid, (1999) The Illustration of Nahj Al-Balagheh, Researched by: Muhammad Abo Al-Fazl Ibrahim, publisher: Dar Ihya Al-Kotob Al-Arabiah, v.16,p.212.

4. Ibn Manzour, Muhammad Ibn Mukram ,(1997) Lissan Al-Arab, publisher: Dar Sadir ,v.12,p.404.

5. Baha Al-Dini, Seyed Reza , (2003) the Ladder of the Sky, editted by Akbar Asadi, publisher: Qum Fekravaran ,p.247.

6. Khumeini, Rooh Allah , (2003) The Illustration of forty Hadithes, publisher: The Institution of Editting and Publication of Imam Khumeini's works ,p.5.

7. Tabatabaei, Muhammad Hussein,(1996) Almizan Fi Tafsir Al-Quran, Translated by: Muhammad Bagher Mussavi ,Publisher: The Office of Qum Hawze Ilmieh Teachers'society v.16:313, , v.2:130\& 138 \&335, v.19:378 -379,v.20:p.385.

8. Tabatabaei,Ali,(2006)The perfect Man ,publisher:Relegious Publications , pp . 120 , 145 ,134.

9. Tabarsi , Ahmad Ibn Ali , (2007) Al-Ihtijaj ,publisher: Matabi' Al-Na'man, v.1:p.272,274.

10. Farahidi,KHalil Ibn Ahmad,(2013) Kitab Al-Ein ,Publisher: Osveh Publications,v.1,p.369. 
11. Gharashi,Ali Akbar ,(1998) Ahsan Al-Hadith Egesesis, publisher:Be'sat Foundation,v.11,p.44.

12. Kuleini, Muhammad Ibn Yaqub, (no date) Asoole Kafi, translated and illustrated by: Javad Mustafavi, publisher:Ahle Beit's Culture Publication Office , v.1:pp.10\&11.

13. Majlessi, Muhammad Bagher , (1982)Bihar Al-Anvar ,publisher: Al-Vafa Institution v.70:p.55,v.94:p.142,v.58:p.25,v.26:p.67.

14. Muhammadi Reishahri, Muhammad,(2006) Mizan Al-Hikmah ,publisher: Dar Al-Hadith ,v.4,p.215.

15. Mustafavi, Hassan,(1971)Researching in the Holy Quran's Lexicons, publisher: Book Publication \& Translation Agency ,v.8,p.154.

Yousefian, Hassan, (2009) Research in the Innocents' innocence, publisher:Islamic thought and culture Institute , pp.43-45. 